\title{
Seroprevalence of 12 serovars of pathogenic Leptospira in red foxes (Vulpes vulpes) in Poland
}

\author{
Jacek Żmudzki ${ }^{*}$, Zbigniew Arent ${ }^{2}$, Artur Jabłoński ${ }^{1}$, Agnieszka Nowak1', Sylwia Zębek , Agnieszka Stolarek², \\ $Ł_{\text {Łukasz Bocian }}^{3}$, Adam Brzana ${ }^{4}$ and Zygmunt Pejsak ${ }^{1}$
}

\begin{abstract}
Background: Leptospira spp. infect humans and a wide range of domestic and wild animals, but certain species such as small rodents and red foxes (Vulpes vulpes) play a particular role as reservoirs and transmission of leptospirosis as they easily adapt to many habitats including human environments. To investigate the significance of red foxes in the epidemiology of leptospirosis in Poland, a seroprevalence survey was conducted. During the 2014-2015 hunting season, blood samples of 2134 red foxes originating from the central-eastern part of Poland were collected. Serum samples were tested by a microscopic agglutination test for the presence of specific antibodies to Leptospira serovars Icterohaemorrhagiae, Grippotyphosa, Sejroe, Tarassovi, Pomona, Canicola, Hardjo, Ballum, Australis, Bataviae, Saxkoebing and Poi.
\end{abstract}

Results: Antibodies to at least one serovar were detected in 561 sera (26.3\%). The highest seroprevalence was found in the Subcarpathia (41.6\%) and Warmia-Masuria (40.3\%) provinces. Antibodies were mainly directed against serovars Poi (12.4\%), Saxkoebing (11.3\%), and Sejroe (6.0\%).

Conclusions: Exposure of red foxes to certain Leptospira serovars seems to be common in central and eastern Poland. In addition, the high prevalence of antibodies against Leptospira spp. in foxes may indicate a potential risk of infection for humans and other species coming into contact with these animals.

Keywords: Leptospirosis, Prevalence, Red fox, Serology, Vulpes vulpes, Zoonosis

\section{Background}

Leptospirosis caused by pathogenic spirochetes of the genus Leptospira is an important but sometimes neglected infection that affects people and animals worldwide. Leptospirosis is a re-emerging major public health problem in many countries and is one of the most widespread zoonoses. It is an excellent example validating the "One Health" approach, where the relationship between humans, animals and ecosystems needs to be considered in order to better understand and manage a disease [1]. Some serovars of Leptospira can chronically infect domestic and wild animals and in particular small

\footnotetext{
*Correspondence: jaca@piwet.pulawy.pl

1 Swine Diseases Department, National Veterinary Research Institute,

Partyzantow 57, 24-100 Pulawy, Poland

Full list of author information is available at the end of the article
}

rodents. In addition to rodents, other wild animal species such as the red fox (Vulpes vulpes) may act as a reservoir [2]. The bacteria are occasionally transmitted through direct contact with mammal hosts, but the majority are usually transmitted via contact with contaminated soil and water [3], where leptospires' survival outside the host is favoured by warm moist conditions [4]. The red fox lives throughout Europe, mainly inhabiting forests, meadows, coastal dunes and urbanized areas [5]. The Polish hunting statistics for 2015 indicate that the population of red foxes in Poland is 190,000-200,000 individuals, with a tendency to remain stable [6]. Red foxes prey upon small rodents, among other animals and the red fox may transmit leptospirosis to humans. A recent study indicate that small mammals might be an important source of human leptospirosis as both rodents and 
humans share infections caused by Leptospira spp. from the same serogroups [7]. The aim of the present study was to determine the seroprevalence for Leptospira spp. in red foxes from central and eastern Poland.

\section{Methods}

\section{Sample collection and study area}

Blood samples from red foxes $(n=2134)$ were collected during the 2014-2015 hunting seasons in Poland. Blood was taken from the thoracic cavity or heart of animals culled primarily through the rabies monitoring program. Sex and geographic location were recorded and age was determined by the degree of dentine surface wear and tooth eruption (juveniles: $<1$ year; mature $>1$ year) (Table 1). The samples originated from 134 counties of nine provinces of Poland and were mainly collected from the central and eastern $\left(49-55^{\circ} \mathrm{N}, 17-23^{\circ} \mathrm{E}\right)$ parts of the country (Fig. 1). Blood samples were centrifuged at $4500 \mathrm{~g}$ for $30 \mathrm{~min}$ and serum stored at $-20{ }^{\circ} \mathrm{C}$ until analysis.

\section{Microscopic agglutination test}

Serum samples were tested by a microscopic agglutination test (MAT) using a range of 12 Leptospira serovars representative of 10 serogroups found in Europe: Icterohaemorrhagiae (RGA strain, representing the Icterohaemorrhagiae serogroup), Grippotyphosa (Moskva V strain, Grippotyphosa serogroup), Sejroe (M84 strain, Sejroe serogroup), Tarassovi (Perepelicyn strain, Tarassovi serogroup), Pomona (Pomona strain, Pomona serogroup), Canicola (Hond Utrecht IV strain, Canicola serogroup), Hardjo (Hardjoprajitno strain, Sejroe serogroup), Ballum (MUS127 strain, Ballum serogroup), Australis (Ballico strain, Australis serogroup), Bataviae (Swart strain, Bataviae serogroup), Saxkoebing (MUS 24 strain, Sejroe serogroup) and Poi (Poi strain, Javanica serogroup) $[8,9]$. The selection of the serovars used was based on their common identification in previous European studies [10-13] reporting Leptospira spp. in wild carnivores.

Each serovar was grown in $10 \mathrm{~mL}$ of EllinghausenMcCullough-Johnson-Harris (EMJH) medium, at $30 \pm 1{ }^{\circ} \mathrm{C}$ for at least 4 but no more than 8 days depending on the serovar. The concentration of bacteria was adjusted to $1-2 \times 10^{8}$ cells $/ \mathrm{mL}$ using a Helber counting chamber. The sera were initially diluted 1:50 and screened for antibodies to the 12 serovars. A volume of each antigen equal to the diluted serum volume was added to each well with a final serum dilution of 1:100 in the screening test. The final concentration of antigen after mixing with the diluted serum was $1-2 \times 10^{4}$ cells/ $\mathrm{mL}$. The plates were incubated at $30 \pm 1{ }^{\circ} \mathrm{C}$ for $2-4 \mathrm{~h}$ and subsequently examined by dark-field microscopy. The titre was defined as the highest dilution where $\geq 50 \%$ of the antigen suspension added to the tested serum was agglutinated. When agglutination was observed, the relevant sera were end-point tested using twofold dilutions ranging from $1: 100$ to $1: 25,600$.

The quality control of the MAT was performed by using certified reference Leptospira strains and anti-Leptospira rabbit antisera (Veterinary Sciences Division, AFBI, OIE Leptospira Reference Laboratories, Belfast, and the WHO/FAO and National Collaborating Centre for Reference and Research on Leptospirosis, Royal Tropical Institute (KIT), Amsterdam, the Netherlands). Testing of the samples was conducted at the National Reference Laboratory of Leptospirosis, National Veterinary Research Institute in Pulawy, Poland using an accredited method according to PN/EN ISO/IEC 17025-2005.

\section{Statistical analysis}

Statistical analysis was used to study the impact of the season, sex, age, region and population density of foxes on Leptospira seroprevalence. It was based on logistic regression models to describe the influence of several variables $X_{1}, X_{2}, \ldots, X_{n}$ on the dichotomous variable $Y$ :

$$
P\left(Y=1 \mid x_{1}, x_{2}, \ldots, x_{n}\right)=\frac{e^{\left(\beta_{0}+\sum_{i=1}^{n} \beta_{i} x_{i}\right)}}{1+e^{\left(\beta_{0}+\sum_{i=1}^{n} \beta_{i} x_{i}\right)}}
$$

where $\beta_{i}$ is the regression coefficient for $i=0, \ldots, n, \chi_{i}$ are independent variables (measurable or qualitative) for $i=1,2, \ldots, n$.

The maximum likelihood method was used to estimate the model's coefficients. The Wald test was used to evaluate the significance of individual variables. Evaluation of model fit to data was performed using the likelihood ratio (LR) test.

Five predictors ( 4 qualitative and 1 quantitative) were included in the modelling:

- sampling season (spring: March-May, summer: June-August, autumn: September-November, or winter: December-Feburary);

- $\operatorname{sex}$ (male, female);

- age (young, adult);

- province (LD: Łódzkie; MP: Lesser Poland; MA: Masovia; OP: Opolskie; PK: Subcarpathia; PM: Pomerania; SL: Silesia; SW: Świętokrzyskie; WM: WarmiaMasuria); (Fig. 1) and

- fox density in counties in $2015\left(\mathrm{No} / \mathrm{km}^{2}\right)$.

The dependent variable was the qualitative result of the study. Analysis was performed for results without distinguishing between serovars (Leptospira spp.: positive/ 


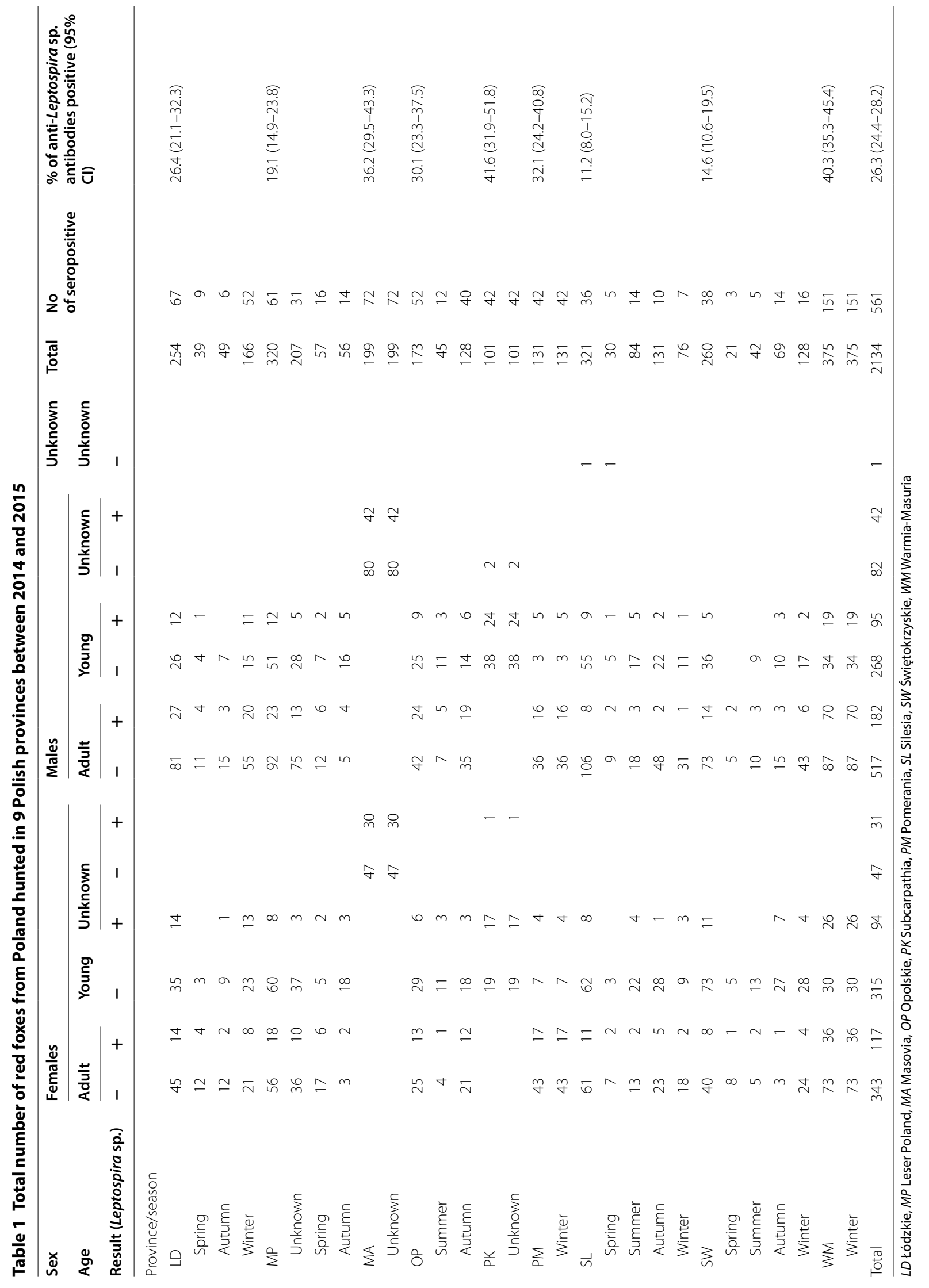






negative) and for each serovar separately. The selection of variables for modelling was based on analytical stepping methods (step-wise). For qualitative variables, 0-1 coding for $\mathrm{k}-1$ variables was used (Table 2).

The following classes of variables were reference classes in models: 'summer' for sampling season, 'female' for sex, 'young' for age and 'SL' for province. Parameters of significant and best fit logistic regression models obtained for each analysis are shown in Table 3. The accepted
Table 2 Dichotomous coding for qualitative variables with an example of sampling season

\begin{tabular}{llll}
\hline Sampling season & Spring & Autumn & Winter \\
\hline Spring & 1 & 0 & 0 \\
Summer & 0 & 0 & 0 \\
Autumn & 0 & 1 & 0 \\
Winter & 0 & 0 & 1 \\
\hline
\end{tabular}


Table 3 Results of the best fit logistic regression models obtained for each analysis

\begin{tabular}{|c|c|c|c|c|c|c|c|}
\hline $\begin{array}{l}\text { Significance assessment } \\
\text { of model ( } P \text { value of LR } \\
\text { test) }\end{array}$ & Independent variable & Coefficient $\left(\beta_{i}\right)$ & Std. error & $P$ value (Wald) & Odds ratio & $\begin{array}{l}\text { Confidence } \\
\text { OR }-95 \%\end{array}$ & $\begin{array}{l}\text { Confidence } \\
\text { OR }+95 \%\end{array}$ \\
\hline \multicolumn{8}{|c|}{ Models for infection of Leptospira sp. (without distinction of serovars) } \\
\hline \multirow[t]{10}{*}{$<0.001$} & Absolute term $\left(\beta_{0}\right)$ & -2.92912 & 0.296482 & $<0.001$ & 0.05 & 0.03 & 0.10 \\
\hline & LD & 1.216036 & 0.233494 & $<0.001$ & 3.37 & 2.13 & 5.33 \\
\hline & MP & 0.671037 & 0.228562 & 0.003 & 1.96 & 1.25 & 3.06 \\
\hline & MA & 1.68051 & 0.237135 & $<0.001$ & 5.37 & 3.37 & 8.55 \\
\hline & $\mathrm{OP}$ & 1.388372 & 0.247953 & $<0.001$ & 4.01 & 2.46 & 6.52 \\
\hline & PK & 1.769046 & 0.269941 & $<0.001$ & 5.87 & 3.45 & 9.96 \\
\hline & PM & 1.534127 & 0.265823 & $<0.001$ & 4.64 & 2.75 & 7.81 \\
\hline & SW & 0.555254 & 0.259964 & 0.03 & 1.74 & 1.05 & 2.90 \\
\hline & WM & 1.630786 & 0.20659 & $<0.001$ & 5.11 & 3.41 & 7.66 \\
\hline & Fox density (No/km²) & 1.142803 & 0.307487 & $<0.001$ & 3.14 & 1.72 & 5.73 \\
\hline \multirow{4}{*}{$<0.001$} & Absolute term $\left(\beta_{0}\right)$ & -1.50766 & 0.198255 & $<0.001$ & 0.22 & 0.15 & 0.33 \\
\hline & Spring & 0.267965 & 0.280004 & 0.34 & 1.31 & 0.75 & 2.26 \\
\hline & Autumn & 0.0834 & 0.232275 & 0.72 & 1.09 & 0.69 & 1.71 \\
\hline & Winter & 0.688467 & 0.211402 & 0.001 & 1.99 & 1.31 & 3.01 \\
\hline \multicolumn{8}{|c|}{ Model for Icterohaemorrhagiae } \\
\hline \multirow[t]{3}{*}{0.003} & Absolute term $\left(\beta_{0}\right)$ & -6.41457 & 0.839692 & $<0.001$ & 0.002 & 0.0003 & 0.008 \\
\hline & Fox density ( $\left.\mathrm{No} / \mathrm{km}^{2}\right)$ & 2.913659 & 0.989553 & 0.003 & 18.42 & 2.65 & 128.30 \\
\hline & Adult & -1.18961 & 0.553268 & 0.03 & 0.30 & 0.10 & 0.90 \\
\hline \multicolumn{8}{|l|}{ Model for Grippotyphosa } \\
\hline \multirow{2}{*}{0.001} & Absolute term $\left(\beta_{0}\right)$ & -5.71115 & 0.543301 & $<0.001$ & 0.003 & 0.001 & 0.01 \\
\hline & Fox density $\left(\mathrm{No} / \mathrm{km}^{2}\right)$ & 2.364823 & 0.677533 & $<0.001$ & 10.64 & 2.82 & 40.19 \\
\hline \multicolumn{8}{|l|}{ Model for Sejroe } \\
\hline \multirow[t]{9}{*}{0.015} & Absolute term $\left(\beta_{0}\right)$ & -3.43721 & 0.318798 & $<0.001$ & 0.03 & 0.02 & 0.06 \\
\hline & LD & 1.130284 & 0.386552 & 0.003 & 3.10 & 1.45 & 6.61 \\
\hline & MP & 0.35268 & 0.419714 & 0.40 & 1.42 & 0.62 & 3.24 \\
\hline & MA & 0.85591 & 0.422493 & 0.04 & 2.35 & 1.03 & 5.39 \\
\hline & $\mathrm{OP}$ & 0.110974 & 0.514159 & 0.83 & 1.12 & 0.41 & 3.06 \\
\hline & PK & 1.228934 & 0.461089 & 0.008 & 3.42 & 1.38 & 8.44 \\
\hline & PM & 1.047612 & 0.44818 & 0.02 & 2.85 & 1.18 & 6.87 \\
\hline & SW & 0.408686 & 0.434724 & 0.35 & 1.50 & 0.64 & 3.53 \\
\hline & WM & 0.880843 & 0.376223 & 0.02 & 2.41 & 1.15 & 5.05 \\
\hline \multicolumn{8}{|l|}{ Model for Australis } \\
\hline \multirow[t]{2}{*}{$<0.001$} & Absolute term $\left(\beta_{0}\right)$ & -6.36907 & 0.610643 & $<0.001$ & 0.002 & 0.0005 & 0.01 \\
\hline & Fox density $\left(\mathrm{No} / \mathrm{km}^{2}\right)$ & 2.843724 & 0.730836 & $<0.001$ & 17.18 & 4.10 & 72.02 \\
\hline \multicolumn{8}{|l|}{ Models for Saxkoebing } \\
\hline \multirow[t]{4}{*}{0.024} & Absolute term $\left(\beta_{0}\right)$ & -2.77882 & 0.325736 & $<0.001$ & 0.06 & 0.03 & 0.12 \\
\hline & Spring & 0.445929 & 0.436438 & 0.31 & 1.56 & 0.66 & 3.68 \\
\hline & Autumn & 0.408323 & 0.368228 & 0.27 & 1.50 & 0.73 & 3.10 \\
\hline & Winter & 0.806557 & 0.34165 & 0.02 & 2.24 & 1.15 & 4.38 \\
\hline
\end{tabular}


Table 3 (continued)

\begin{tabular}{|c|c|c|c|c|c|c|c|}
\hline $\begin{array}{l}\text { Significance assessment } \\
\text { of model ( } P \text { value of } L R \\
\text { test) }\end{array}$ & Independent variable & Coefficient $\left(\beta_{i}\right)$ & Std. error & $P$ value (Wald) & Odds ratio & $\begin{array}{l}\text { Confidence } \\
\text { OR }-95 \%\end{array}$ & $\begin{array}{l}\text { Confidence } \\
\text { OR }+95 \%\end{array}$ \\
\hline \multirow[t]{9}{*}{$<0.001$} & Absolute term $\left(\beta_{0}\right)$ & -2.94772 & 0.25661 & $<0.001$ & 0.05 & 0.03 & 0.09 \\
\hline & LD & 1.010782 & 0.318737 & 0.002 & 2.75 & 1.47 & 5.13 \\
\hline & MP & 0.715284 & 0.318663 & 0.03 & 2.04 & 1.09 & 3.81 \\
\hline & MA & 1.257746 & 0.322546 & $<0.001$ & 3.52 & 1.87 & 6.62 \\
\hline & OP & 1.021486 & 0.343397 & 0.003 & 2.78 & 1.42 & 5.45 \\
\hline & PK & 1.939495 & 0.341159 & $<0.001$ & 6.96 & 3.56 & 13.58 \\
\hline & PM & 1.452948 & 0.341859 & $<0.001$ & 4.28 & 2.19 & 8.36 \\
\hline & SW & -0.63976 & 0.461137 & 0.17 & 0.53 & 0.21 & 1.30 \\
\hline & WM & 1.121314 & 0.296979 & $<0.001$ & 3.07 & 1.71 & 5.49 \\
\hline \multicolumn{8}{|l|}{ Models for Poi } \\
\hline \multirow[t]{10}{*}{$<0.001$} & Absolute term $\left(\beta_{0}\right)$ & -5.45234 & 0.689411 & $<0.001$ & 0.004 & 0.001 & 0.02 \\
\hline & LD & 2.814176 & 0.617742 & $<0.001$ & 16.68 & 4.97 & 56.01 \\
\hline & MP & 1.032509 & 0.682165 & 0.13 & 2.81 & 0.74 & 10.70 \\
\hline & MA & 3.445862 & 0.612244 & $<0.001$ & 31.37 & 9.44 & 104.22 \\
\hline & OP & 3.293047 & 0.618209 & $<0.001$ & 26.92 & 8.01 & 90.51 \\
\hline & PK & 2.239957 & 0.687842 & 0.001 & 9.39 & 2.44 & 36.19 \\
\hline & PM & 2.960175 & 0.643965 & $<0.001$ & 19.30 & 5.46 & 68.24 \\
\hline & SW & 2.610502 & 0.629299 & $<0.001$ & 13.61 & 3.96 & 46.74 \\
\hline & WM & 3.666819 & 0.591781 & $<0.001$ & 39.13 & 12.26 & 124.88 \\
\hline & Fox density (No/km²) & 1.043369 & 0.476866 & 0.03 & 2.84 & 1.11 & 7.23 \\
\hline \multirow[t]{4}{*}{$<0.001$} & Absolute term $\left(\beta_{0}\right)$ & -2.89037 & 0.342638 & $<0.001$ & 0.06 & 0.03 & 0.11 \\
\hline & Spring & 0.375612 & 0.464447 & 0.42 & 1.46 & 0.59 & 3.62 \\
\hline & Autumn & 0.519876 & 0.383324 & 0.18 & 1.68 & 0.79 & 3.57 \\
\hline & Winter & 1.368756 & 0.353764 & $<0.001$ & 3.93 & 1.96 & 7.87 \\
\hline \multirow[t]{2}{*}{0.003} & Absolute term $\left(\beta_{0}\right)$ & -2.30544 & 0.125369 & 0 & 0.10 & 0.08 & 0.13 \\
\hline & Adult & 0.437116 & 0.152208 & 0.004 & 1.55 & 1.15 & 2.09 \\
\hline
\end{tabular}

LD Łódzkie, MP Leser Poland, MA Masovia, OP Opolskie, PK Subcarpathia, PM Pomerania, SW Świętokrzyskie, WM Warmia-Masuria

significance level was alpha $=0.05$. STATISTICA data analysis software in version 10 (StatSoft, Inc.) and ArcGIS 10.4.1 for Desktop Standard (ESRI, Inc.) were used for statistical and spatial data analysis. Red fox demographics were derived from the Polish Hunting Association-PZL [6].

\section{Results}

Antibodies against a Leptospira serovar was found in 561 serum samples $(26.3 \%)$. The highest seroprevalence was observed in foxes hunted in the Subcarpathia (41.6\%) and Warmia-Masuria provinces (40.3\%) (Table 1, Fig. 1). Specific antibodies were mainly directed against Poi (12.4\%), Saxkoebing (11.3\%), and Sejroe (6.0\%) serovars with serum antibody titres up to 1:25,600 in individual animals (Table 4). When analysing the logistic regression model of positive and negative serostatus (excluding data related to individual Leptospira serovars), a significant influence of the area (province) and associated density of foxes on the serostatus was found. The model showed that all provinces had significantly greater odds for having seropositive foxes than the reference SL province, in which the lowest percentage of seropositive foxes was observed. The highest odds ratio $(\mathrm{OR}=5.87)$ with the highest seroprevalence was shown for the PK province. In addition, with an increase of fox density by one animal per $\mathrm{km}^{2}$, the probability of detecting seropositive animals increased more than threefold and it almost doubled in winter when compared to summer. However due to data deficiencies e.g. sampling date, seasonal influence on the obtained serological results was analysed using a separate logistic regression model.

Based on analyses for individual serovars, an increase of fox density by one animal per $\mathrm{km}^{2}$ increased the risk of being seropositive by 2.8, 10.6, 17.2 and 18.4 times for the serovars Poi, Grippotyphosa, Australis and Icterohaemorrhagiae, respectively. The models also show a significant influence of the province on the proportion of seropositive samples. A significantly higher risk of being seropositive to Sejroe serovar was observed in the LD 
Table 4 Distribution of pathogenic Leptospira antibody titers for 561 positive red foxes hunted during season 2014-2015 in Poland

\begin{tabular}{|c|c|c|c|c|c|c|c|c|c|c|c|}
\hline \multirow[t]{2}{*}{ Serovar } & \multicolumn{10}{|c|}{ No of antibody-positive samples (\%) } & \multirow{2}{*}{$\begin{array}{l}\text { Prevalence } \\
\text { of serovar }(95 \% \\
\text { CI) }(\%)\end{array}$} \\
\hline & $1: 100$ & $1: 200$ & $1: 400$ & $1: 800$ & $1: 1600$ & $1: 3200$ & $1: 6400$ & $1: 12800$ & $1: 25600$ & Total & \\
\hline Icterohaemorrhagiae & $8(0.4)$ & $3(0.1)$ & $3(0.1)$ & $1(0.05)$ & $2(0.1)$ & $1(0.05)$ & 0 & 0 & 0 & 18 & $0.8(0.5-1.3)$ \\
\hline Grippotyphosa & $6(0.3)$ & $16(0.75)$ & $8(0.4)$ & $4(0.2)$ & $1(0.05)$ & $2(0.1)$ & 0 & 0 & 0 & 37 & $1.7(1.2-2.4)$ \\
\hline Sejroe & $39(1.8)$ & $37(1.7)$ & $30(1.4)$ & $16(0.75)$ & $2(0.1)$ & $2(0.1)$ & 0 & 0 & $1(0.05)$ & 127 & $6.0(5.0-7.0)$ \\
\hline Tarassovi & 0 & $1(0.05)$ & 0 & 0 & 0 & 0 & 0 & 0 & 0 & 1 & $0.1(0.0-0.3)$ \\
\hline Pomona & $7(1.5)$ & $7(1.5)$ & $8(0.4)$ & $8(0.4)$ & $2(0.1)$ & $2(0.1)$ & 0 & 0 & 0 & 34 & $1.6(1.1-2.2)$ \\
\hline Canicola & 0 & $2(0.1)$ & $1(0.05)$ & 0 & 0 & 0 & 0 & 0 & 0 & 3 & $0.1(0.0-0.4)$ \\
\hline Australis & $7(1.5)$ & $11(0.5)$ & $1(0.05)$ & $7(1.5)$ & $2(0.1)$ & 0 & 0 & 0 & 0 & 28 & $1.3(0.9-1.9)$ \\
\hline Saxkoebing & $63(3.0)$ & $55(2.6)$ & $66(3.1)$ & $44(2.1)$ & $8(0.4)$ & $3(0.1)$ & $2(0.1)$ & 0 & $1(0.05)$ & 242 & $11.3(10.0-12.8)$ \\
\hline Ballum & 0 & $1(0.05)$ & $1(0.05)$ & $1(0.05)$ & 0 & 0 & 0 & 0 & 0 & 3 & $0.1(0.0-0.4)$ \\
\hline Poi & $64(3.0)$ & $68(3.2)$ & $63(3.0)$ & $34(1.6)$ & $11(0.5)$ & $19(0.9)$ & $4(0.2)$ & $1(0.05)$ & $1(0.05)$ & 265 & $12.4(11.1-13.9)$ \\
\hline Bataviae & $1(0.05)$ & $1(0.05)$ & $3(0.1)$ & $3(0.1)$ & 0 & $1(0.05)$ & 0 & 0 & 0 & 9 & $0.4(0.2-0.8)$ \\
\hline Hardjo & 0 & $2(0.1)$ & 0 & $1(0.05)$ & 0 & 0 & $1(0.05)$ & 0 & 0 & 4 & $0.2(0.1-0.5)$ \\
\hline
\end{tabular}

$(\mathrm{OR}=3.1)$, MA $(\mathrm{OR}=2.4)$, $\mathrm{PK}(\mathrm{OR}=3.4), \mathrm{PM}(\mathrm{OR}=2.9)$ and WM $(\mathrm{OR}=2.4)$ provinces compared to the $\mathrm{SL}$ province.

When compared to the reference SL province, antibodies to the Saxkoebing and Poi serovars were more prevalent in foxes from all provinces except SW (OR from 2.0 to 7.0), and MP province (OR from 9.4 to 39.1) respectively. An impact of the season on the seroprevalence to particular serovars was observed. Antibodies against serovars Saxkoebing and Poi were $\sim 2$ and 4 times more frequent, respectively, during the winter period than during summer. The age of the foxes influenced the serostatus for some serovars such as Icterohaemorrhagiae that was detected more frequently in young foxes $(\mathrm{OR}=3.3)$ and Poi found more often in adults $(\mathrm{OR}=1.5)$ (Table 3). Using a one-factor model the association between influence of sex on serostatus was not significant (LR-test $\mathrm{P}=0.0525$, OR $=1.44,95 \%$ CI 0.99-2.09).

\section{Discussion}

Other serological surveys have shown that red foxes are frequently exposed to Leptospira spp. of different serovars $[10,11,13]$. However this is the first prevalence study on the occurrence of antibodies to a broad range of Leptospira serovars in a red fox population in eastern Europe. The high seroprevalence (26.3\%) in red foxes in Poland is comparable to that found in Spain (47.1\%) [10] and Croatia (31.3\%) [13] but higher than in other European countries such as Germany (1.9\%) [14] and Norway (9.9\%) [11]. Hypothetically any pathogenic Leptospira may infect domestic and wild animals, but in practice only a small number of serovars are endemic in any particular region.
Antibodies against serovar Poi were the most commonly detected. Exposure of foxes to this serovar is not surprising given the results of previous Polish studies where serogroup Javanica (to which serovar Poi belongs) was also reported in horses, goats, and sheep [15-17]. Besides serovar Poi, antibodies against serovar Sejroe were also prevalent in foxes. This is consistent with other studies as serovars Hardjo, Sejroe and Saxkoebing (all belonging to the Sejroe serogroup) are widely prevalent in animals in Europe [18-21]. MAT reactions to serovar Hardjo commonly detected in sheep and cattle [18-20, $22,23]$ were not common in foxes. The presence of seropositive animals to this serogroup could be mainly attributed to Sejroe or Saxkoebing serovars (Table 4). It may be associated with fox diet as the main source of food for red foxes are wild small mammals, which are known reservoirs of Saxkoebing and Sejroe serovars [24]. Antibodies to Sejroe serogroup were previously detected in pigs, dogs, horses and cattle in Poland confirming a widespread exposure of different animal species to leptospires from this serogroup [15, 25-28]. In addition, this indicates an endemic occurrence of this serovar and a possible role of the environment in pathogen transmission. The observed regional differences in exposure to different Leptospira serovars may be related to active circulation of Leptospira spp. in the environment [12].

Studies conducted in other European countries provide scientific evidences that the most common serovar among red foxes is serovar Icterohaemorrhagiae [10, 11, 13], which however seems to be rare in the Polish red fox population (Table 4). As leptospires are sensitive to desiccation, the regional differences in climate conditions may have a significant influence on seroprevalence in general 
or for some serovars in particular. In that aspect, Poland differs from other countries such as Spain and Croatia where the seroprevalence of Leptospira spp. in foxes has been investigated $[10,13]$.

Although the studies were conducted on a reasonable number of hunted animals originating from different locations across the country, the number of tested serum samples of red foxes did not fully reflect the size of the animal population present in the studied provinces. It could be taken as a major limitation to interpretation of the occurrence and prevalence of tested Leptospira serovars in the Polish population of red foxes. Nevertheless, the findings still provide useful data on the seroepidemiology of red foxes exposed to different Leptospira serovars in this part of Europe and their role as an important source of zoonotic Leptospira spp. for humans.

\section{Conclusions}

Red foxes of central and eastern Poland, particularly in the Subcarpathia and Warmia-Masuria regions, are highly exposed to Leptospira spp. Due to the high prevalence of foxes, their predatory behaviour and their varied diet mainly composed of small mammals, they could be considered as sentinel animals of environmental contamination with leptospires. Interactions between animals require further epidemiological investigations to elucidate the role of wild carnivores as a reservoir of rarely occurring Leptospira serovars pathogenic for other animals and humans.

\section{Abbreviations \\ DS: Lower Silesia; EMJH: Ellinghausen-McCullough-Johnson-Harris medium; KP: Kuyavian-Pomerania; LB: Lubuskie; LD: Łódzkie; LR: likelihood ratio; LU: Lubelskie; MA: Masovia; MAT: microscopic agglutination test; MP: Lesser Poland; OP: Opolskie; OR: odds ratio; PD: Podlaskie; PK: Subcarpathia; PM: Pomerania; SL: Silesia; SW: Świętokrzyskie; WM: Warmia-Masuria; WP: Greater Poland; ZP: West Pomerania.}

\section{Authors' contributions}

JZ designed and coordinated the study. SZ and AN were responsible for the laboratory work and preliminary data analysis under the supervision of JZ, AJ and ZP. AS was involved in the analyses of epidemiological data. LB performed the statistical analyses. ZA, AJ and AB had the main responsibility of checking and authoring the manuscript. All authors read and approved the final manuscript.

\section{Author details \\ ${ }^{1}$ Swine Diseases Department, National Veterinary Research Institute, Partyz- antow 57, 24-100 Pulawy, Poland. ${ }^{2}$ University Centre of Veterinary Medicine UJ-UR, University of Agriculture in Krakow, Mickiewicza 24/28, 30-059 Krakow, Poland. ${ }^{3}$ Epidemiology and Risk Assessment Department, National Veterinary Research Institute, Partyzantow 57, 24-100 Pulawy, Poland. ${ }^{4}$ Veterinary Hygiene Research Station, Wroclawska 170, 45-836 Opole, Poland.}

\section{Acknowledgements}

We are grateful to the hunters of all nine provinces. Many thanks to Jolanta Sajna from the Warsaw Veterinary Hygiene Research Station (Ostrołęka field division) and to Zofia Klimczak from the Bydgoszcz Veterinary Hygiene Research Station for data and serum samples from foxes; without their help this investigation would not have been possible. The authors would like to warmly thank Artur Rzeżutka for useful comments and editing of the manuscript.

\section{Competing interests}

The authors declare that they have no competing interests.

Availability of data and materials

All data generated or analysed during this study are included in this published article.

\section{Consent for publication \\ Not applicable.}

\section{Ethics approval and consent to participate}

All procedures were carried out according to the ethical standards for the use of animal samples. The study was approved by the Ethical Committee of the University of Life Sciences in Lublin under Grant of Approval No. 30/2016.

\section{Funding}

This study was supported by the Polish National Science Centre (Grant No. 2013/09/B/NZ7/02563). The open access publication fee was funded by the KNOW (Leading National Research Centre) Scientific Consortium "Healthy Animal—Safe Food", Ministry of Science and Higher Education resolution no. 05-1/KNOW2/2015".

\section{Publisher's Note}

Springer Nature remains neutral with regard to jurisdictional claims in published maps and institutional affiliations.

Received: 7 September 2017 Accepted: 24 May 2018

Published online: 31 May 2018

\section{References}

1. Jancloes M, Bertherat E, Scheider C, Belmain S, Munoz-Zanzi C, Hartskeerl $R$, et al. Towards a "one health" strategy against leptospirosis. Planet@Risk. 2014;2:204-6 (Special Issue on One Health (Part I/II): GRF Davos).

2. Levett PN. Leptospirosis. Clin Microbiol Rev. 2001;14:296-326.

3. Bharti AR, Nally JE, Ricaldi JN, Matthias MA, Diaz MM, Lovett MA, et al. Leptospirosis: a zoonotic disease of global importance. Lancet Infect Dis. 2003;3:757-71.

4. Ellis WA. Leptospirosis: Leptospira spp. serovars Pomona, Kennewicki, Bratislava, Muenchen, Tarassovi, Canicola, Grippotyphosa, Hardjo, others_-abortion and stillbirths. In: Zimmerman JJ, Karriker LA, Ramirez A, Schwartz KJ, Stevenson GW, editors. Diseases of swine. 10th ed. New York: Wiley; 2012. p. 770-8.

5. National Geographic. Animals. Washington, D.C. 2017. https://www.natio nalgeographic.com/animals/mammals/r/red-fox/. Accessed 04 Mar 2018.

6. Polish Hunting Association-PZL. Warsaw. 2015. http://www.czemp in.pzlow.pl/palio/html.run?_Instance=pzl_www\&_PagelD=21\&_ CAT=CZEMPIN.MATERIALY. Accessed 04 Mar 2018.

7. Stritof Majetic Z, Galloway R, Ruzic Sabljic E, Milas Z, Mojcec Perko V, Habus J, et al. Epizootiological survey of small mammals as Leptospira spp. reservoirs in Eastern Croatia. Acta Trop. 2014;131:111-6.

8. OIE Terrestrial Manual 2014. Chapter 2.1.12. Leptospirosis. http://www. oie.int/fileadmin/Home/eng/Health_standards/tahm/2.01.12_LEPTO.pdf. Accessed 04 Mar 2018.

9. Wolff JW. The laboratory diagnosis of leptospirosis. Illinois: Charles C. Thomas Publishers; 1954. p. 31-51

10. Millán J, Candela MG, López-Bao JV, Pereira M, Jiménez MA, León-Vizcaíno L. Leptospirosis in wild and domestic carnivores in natural areas in Andalusia, Spain. Vector Borne Zoonotic Dis. 2009;9:549-54.

11. Akerstedt J, Lillehaug A, Larsen IL, Eide NE, Arnemo JM, Handeland K. Serosurvey for canine distemper virus, canine adenovirus, Leptospira interrogans, and Toxoplasma gondii in free-ranging canids in Scandinavia and Svalbard. J Wildl Dis. 2010;46:474-80.

12. Moinet M, Fournier-Chambrillon C, André-Fontaine G, Aulagnier S, Mesplède A, Blanchard B. Leptospirosis in free-ranging endangered 
European mink (Mustela lutreola) and other small carnivores (Mustelidae, Viverridae) from southwestern France. J Wildl Dis. 2010;46:1141-51.

13. Slavica Ž, Cvetnić Z, Milas Z, Janicki Z, Turk N, Konjevié D, et al. Incidence of leptospiral antibodies in different game species over a 10-year period (1996-2005) in Croatia. Eur J Wildl Res. 2008;54:305-11.

14. Müller $H$, Winkler P. Results of serological studies of Leptospira antibodies in foxes. Berl Munch Tierarztl Wochenschr. 1994;107:90-3.

15. Arent ZJ, Kedzierska-Mieszkowska S. Seroprevalence study of leptospirosis in horses in northern Poland. Vet Rec. 2013:172:269.

16. Czopowicz M, Kaba J, Smith L, Szalus-Jordanow O, Nowicki M, Witkowsk L. Leptospiral antibodies in the breeding goat population of Poland. Vet Rec. 2011;169:230-4.

17. Krawczyk M. Serological studies on leptospirosis in sheep. Med Weter. 1999;55:397-9.

18. Little TW, Stevens AE, Hathaway SC. Serological studies on British isolates of the Sejroe serogroup I. The identification of British isolates of the Sejroe serogroup by the cross agglutinin absorption test. J Hyg (Lond). 1986;97:123-31.

19. Little TW, Stevens AE, Hathaway SC. Serological studies on British isolates of the Sejroe serogroup of leptospira II. An evaluation of the factor analysis method of identifying leptospires using strains belonging to the Sejroe serogroup. Epidemiol Infect. 1987;99:107-15.

20. Slavica A, Dezdek D, Konjevic D, Cvetnic Z, Sindicic M, Stanin D. Prevalence of leptospiral antibodies in the red fox (Vulpes vulpes) population of Croatia. Vet Med (Praha). 2011;56:209-13.
21. Lange S. Seroepidemiological studies of the detection of leptospires of the Sejroe group in cattle in middle Thuringia. Berl Munch Tierarzt| Wochenschr. 1992;105:374-7.

22. Arent Z, Frizzell C, Gilmore C, Mackie D, Ellis WA. Isolation of leptospires from genital tract of sheep. Vet Rec. 2013;173:582.

23. Ellis WA. Animal leptospirosis. In: Adler B, editor. Leptospira and leptospirosis, vol. 387., Current topics in microbiology and immunologyBerlin: Springer; 2015. p. 99-137. https://doi.org/10.1007/978-3-662-45059-8_1.

24. Sebek Z, Sixl W, Sixl-Voigt B, Köck M, Stünzner D, Valova M. First evidence of the leptospirosis natural foci of the serotype Saxkoebing in Austria. Geogr Med Suppl. 1989;2:17-22

25. Krawczyk M. Serological evidence of leptospirosis in animals in northern Poland. Vet Rec. 2005;156:88-9.

26. Wasiński B. Occurrence of Leptospira sp. antibodies in swine in Poland. Bull Vet Inst Pulawy. 2007;51:225-8.

27. Wasiński B, Pejsak Z. Occurrence of leptospiral infections in swine population in Poland evaluated by ELISA and microscopic agglutination test. Pol J Vet Sci. 2010;13:695-9.

28. Wasiński B. Infections of swine caused by Leptospira serovars of serogroup Sejroe-possibilities of recognition with the use of PCR. Bull Vet Inst Pulawy. 2014;58:521-6.
Ready to submit your research? Choose BMC and benefit from:

- fast, convenient online submission

- thorough peer review by experienced researchers in your field

- rapid publication on acceptance

- support for research data, including large and complex data types

- gold Open Access which fosters wider collaboration and increased citations

- maximum visibility for your research: over $100 \mathrm{M}$ website views per year

At BMC, research is always in progress.

Learn more biomedcentral.com/submissions 